\title{
Digital literacy of teachers within Covid-19
}

\section{Alfabetização digital dos professores da Covid-19}

\section{Alfabetización digital de profesores dentro de Covid-19}

\author{
Aygul Zufarovna Ibatova ${ }^{1}$ iD, Anna Vadimovna Gromova1 ${ }^{1}$
}

${ }^{1}$ Tyumen Industrial University, Tyumen, Russia.

Corresponding author:

Aygul Zufarovna Ibatova

Email: aigoul@rambler.ru

Ibatova, A. Z., \& Gromova, A. V. (2021). Digital literacy of teachers within Covid-19. Revista Tempos e Espaços em Educação, 14(33), e16853. http://dx.doi.org/10.20952/revtee.v14i33.16853

\begin{abstract}
The article is devoted to the study of the digital competence of teachers of Surgut branch of Tyumen Industrial University, as well as their opinion on the feasibility of introducing ICT into the structure of students' education. On the basis of the survey, the ways of the ICT used by teachers were identified, the main features of the ICT used in teaching process of different disciplines, the level of digitalization of the educational process were highlighted. The research was carried out on on the basis of Tyumen Industrial University. The data collection procedure included a questionnaire containing 13 questions, of which 11 were closed-ended, with suggested options, and 2 were open. Based on the data obtained, the difficulties encountered by teachers were identified, which prevent introducing modern technologies in the learning process. The article puts forward the idea of changing the approach to training teachers for the process of ICT implementation. The following conclusion is made that the obtained data allow reforming the strategy of educational activity.
\end{abstract}

Keywords: ICT. Internet. Education. Digitalization. Online Learning.

\section{RESUMO}

O artigo é dedicado ao estudo da competência digital dos professores do ramo de Surgut da Tyumen Industrial University, bem como a sua opinião sobre a viabilidade da introdução das TIC na estrutura da educação dos alunos. Com base no inquérito, foram identificadas as formas de utilização das TIC pelos professores, destacaram-se as principais características das TIC utilizadas no processo de ensino das diferentes disciplinas, o nível de digitalização do processo educativo. A pesquisa foi realizada com base na Universidade Industrial de Tyumen. O procedimento de coleta de dados incluiu um questionário contendo 13 questões, sendo 11 fechadas, com sugestões de opções, e 2 abertas. A partir dos dados obtidos, foram identificadas as dificuldades encontradas pelos professores, que impedem a introdução de tecnologias modernas no processo de aprendizagem. 0 artigo apresenta a ideia de mudar a abordagem da formação de professores para o processo de 
implementação das TIC. Conclui-se que os dados obtidos permitem reformular a estratégia da atividade educativa.

Palavras-chave: TIC. Internet. Educação. Digitalização. Aprendizagem Online.

\section{RESUMEN}

El artículo está dedicado al estudio de la competencia digital de los profesores de la rama Surgut de la Universidad Industrial de Tyumen, así como a su opinión sobre la viabilidad de introducir las TIC en la estructura de la educación de los estudiantes. A partir de la encuesta, se identificaron las formas de las TIC utilizadas por los docentes, se destacaron las principales características de las TIC utilizadas en el proceso de enseñanza de las diferentes disciplinas, el nivel de digitalización del proceso educativo. La investigación se llevó a cabo sobre la base de la Universidad Industrial de Tyumen. El procedimiento de recopilación de datos incluyó un cuestionario que contenía 13 preguntas, de las cuales 11 eran cerradas, con opciones sugeridas y 2 abiertas. A partir de los datos obtenidos se identificaron las dificultades encontradas por los docentes, que impiden introducir tecnologías modernas en el proceso de aprendizaje. El artículo plantea la idea de cambiar el enfoque de la formación de profesores para el proceso de implementación de las TIC. Se llega a la siguiente conclusión de que los datos obtenidos permiten reformar la estrategia de actividad educativa.

Palabras clave: TIC. Internet. Educación. Digitalización. Aprendizaje En Línea.

\section{INTRODUCTION}

The rapid technical and informational progress every year makes more and more stringent requirements for modern specialists. Today it is necessary to have not only knowledge, skills or abilities in a particular industry, but competencies. Their development and acquisition is possible only with comprehensive and systematic training, which is one of the most important tasks of higher education in the Russian Federation (Aydin \& Erol, 2021; llyina et al., 2019).

Information competence is one of the most important competencies contributing to both the effective formation of a specialist in a professional environment and the formation of other professional competencies (Sá \& Serpa, 2020).

Information competence today should be possessed not only by young specialists graduating from higher educational institutions, but also by teachers, with the help of whom it is possible to acquire it. Every year our world is becoming more and more globalized, as all spheres of life, including education, have come under the influence of globalization. Therefore, the quality of education is constantly improving through the exchange of teaching experience in different states. Also, an important contribution is made by the development of information technologies, with the help of which the learning process is digitized and transformed (Kaban \& Aş̧̧, 2021).

Almost every modern educational organization today has an ICT infrastructure, but despite its presence, their potential remains not fully realized due to the digital incompetence of teachers. Therefore, the role of the teacher's preparedness for the learning process comes to the fore today. The development and emergence of new information digital technologies serve as an auxiliary tool for improving learning outcomes and improving the quality of education. But only with the systemic training of personnel, their competence in the field of digital technologies will be able to contribute to the competent, comprehensive and effective use of ICT in education (Krainov et al., 2021; Zulkarnain et al., 2020).

Competent teachers will be able to become both mentors and mentors for students in order to contribute to the development of their creative, intellectual potential, leading them to solve the problems and innovate the new challenges of globalization. In the hands of teachers, ICT will be able to become a platform for the further development of students both in scientific and professional activities, because the tools of computers and all kinds of gadgets are so large that they can satisfy almost any needs. Household, everyday integration of ICT in teaching cannot contribute to the 
achievement of high results, since the knowledge of some students may be better than that of the teacher, which will make the learning process boring and not interesting (Zemtsov et al., 2019). Educators come to a higher educational institution for new knowledge and want to receive it from various fields, especially information. Therefore, the integration of ICT into pedagogy is important to improve the teaching and learning process, it can interest and motivate students (Mikheev et al., 2021; Priyadarshini \& Bhaumik, 2020).

In the spring of 2020, the issue of the introduction of electronic teaching methods in higher education became more acute than ever, since in the face of the outbreak of the pandemic caused by the new coronavirus-COVID19, all spheres of life needed to reconsider their organizational structure and try to transform. It was the digital literacy skills that teachers needed to successfully organize an alternative educational method in such a difficult time (Osina et al., 2020; Purnama et al., 2021).

In this article, we assessed the point of view of teachers on the integration of electronic media and ICT into the teaching system, as well as to investigate the factors slowing down this process, to propose measures to overcome this barrier in the educational process by teachers of the branch of the Tyumen Industrial University in the city of Surgut (Khanty-Mansi Autonomous Okrug, Russia).

Based on the above, the relevance of the topic is determined, firstly, by the problem of the process of transforming the education system to new environmental conditions, and secondly, by the gap between the required level of development of digital literacy of teachers and their actual knowledge.

The aim of the study is to determine the digital literacy of teachers and their views on the feasibility of using ICT in the teaching structure.

To achieve the goal of the study, we have identified the following tasks:

1. To identify the main directions of development of the higher education system in the Russian Federation.

2. To identify ways to prevent the aggravation of the problem of digital illiteracy of teachers, technologies for training and education of teachers.

3. Formulate recommendations to improve the efficiency of ICT implementation in the student learning process.

The object of our research is the digital literacy of teachers at the TIU branch in the city of Surgut.

The subject of our research is the peculiarities of ICT implementation in the education system in a higher educational institution.

Study structure:

The study is divided into three parts. The first part examines the problem of digitalization of society, digital illiteracy and the reasons that give rise to it. The second part describes the research methodology, analyzes the data obtained during the questionnaire, compiles a general picture reflecting the views of teachers on the introduction of ICT into the education system, classifies the reasons for its low efficiency. In the third part, the main conclusions of the study are presented, the main recommendations are formulated, following which can help teachers integrate ICT into teaching and integrate themselves into the new educational environment.

\section{METHODOLOGY}

During the research we used the following methods: Analysis, Comparison, Classification and Questionnaire.

The data for the study were collected on the basis of the Tyumen Industrial University. The data collection procedure included a questionnaire containing 13 questions, of which 11 were closed-ended, with suggested options, and 2 were open. The structure of the questionnaire was a 
list of questions that helped characterize the attitude and views of teachers on the use of ICT. 28 teachers took part in the survey: 17 women (60\%) and 11 men (40\%). The questionnaires consisted of three blocks of questions. The first block provided for the definition of the importance and necessity, in the opinion of teachers, of the introduction of ICT into the curriculum, as well as the importance of digital literacy for them. The second block made it possible to determine the directions, means and ICT tools used by teachers. The third block was aimed at identifying the needs of teachers in teaching them the basics of interaction with modern computer technologies.

\section{LITERARURE REVIEW}

According to a study conducted in 2020 by NAFI, only $27 \%$ of Russians have a sufficient level of digital literacy. Such indicators are low for the Russian economy, which is starting to gain momentum. Due to the insufficient level of knowledge and skills in the field of digital technologies, many people and organizations were not ready to work in a remote format in conditions of selfisolation (Aydin \& Erol, 2021; Osina et al., 2020). There are many reasons for this problem, but what definitely cannot be attributed to them is the lack of access to the Internet among the population. Today, almost $96 \%$ of Russians have their own mobile Internet, which indicates a paradox - there is no literacy, but people remain direct participants in the information space (Ilyina et al., 2019; Pelgrum, 2001).

Digital literacy includes the ability to use search engines and find the necessary and useful information, the ability to distinguish bona fide and trustworthy sources of information from unscrupulous ones, knowledge of parental control systems and the ability to use them (Kaban \& Aş̧ı, 2021; Priyadarshini \& Bhaumik, 2020). Therefore, the concept of "literacy" is used to describe these skills, since their presence underlies safe interaction with the Internet space. Users should always be on the alert when using any electronic gadgets, as carelessness and lack of awareness can become the reasons for fraudulent activities.

The digital literacy index is currently calculated using the Digcomp methodology. Within the framework of this concept, the analysis of digital competencies is carried out according to 5 main parameters: information literacy; communication literacy; digital content creation; digital security; skills of solving problems in a digital environment.

This indicator is an objective assessment of the level of knowledge of digital technologies of an individual. The data obtained in the framework of the study show that it is students who have the highest digital literacy index - 61 out of 100, and working students - 64 out of 100. Therefore, we can say that it is students, future specialists, who should be even more familiar with the latest information technologies.

The digitalization of the educational process, the introduction of ICT into the education system and the transition to electronic resources can greatly contribute to an increase in the level of knowledge of students in the field of information technology. ICT has triggered a paradigm shift in education, transforming it by providing new opportunities for teaching, learning and the use of open educational resources that can increase the productivity of education (Miranda, 2007; Osina et al., 2020). ICT can serve as a catalyst for improving the quality of education through the fullest and most systematic use of information available. Information technologies can increase the motivation of students to acquire knowledge and teachers to be creative (Kryukov \& Shakhgeldyan, 2012; Livingstone, 2012; Purnama et al., 2021). ICTs are able to reduce the amount of expenditures on the material support of classrooms by replacing the usual laboratory installations, layouts and models, as well as the time spent by both teachers and students. Taken together, these factors create an apparatus for successfully improving the quality and efficiency of the educational process.

Over the past 20 years, digital and information technologies have penetrated the life of almost every inhabitant of the planet. Every year, mobile Internet, a personal computer or a telephone are becoming more and more accessible to citizens, while their cost is gradually 
decreasing, as the global turnover of gadgets, as well as the coverage area, is increasing. Today, in all densely populated regions of the Russian Federation, every resident has the opportunity to use the Internet, but in some regions there is only a wired one. There are also regions where there is no Internet connection at all or the prices for services provided by telecom operators are so expensive that people cannot afford them. This fact creates many problems in the development of both the economy and education of the region. Therefore, residents of such regions have high hopes for the recently announced program of creating a global satellite Internet coverage Starlink by Elon Musk's SpaceX company. This technology will accelerate the process of globalization of regions that are especially remote from modern communications, not only in Russia, but throughout the world.

In the process of integrating digital technologies into the higher education system, there are still a number of unresolved issues such as the qualification gap, unemployment, low staffing of educational institutions in our country. In many developed countries, information technology is already an integral part of the learning and teaching process, but in the Russian Federation, integrated ICT education still has a bright future.

The process of transformation of the sphere of education in connection with the introduction of the latest technologies began in 1998 by the Ministry of Education of the Russian Federation. A new document was introduced - the Concept of Informatization of the Sphere of Education of the Russian Federation. In accordance with the concept, informatization of education was understood as "a process aimed at implementing the concept of improving the quality of educational content, conducting research and development, introducing, maintaining and developing, replacing traditional information technologies with more effective ones in all types of activities in the education system" (Aydin \& Erol, 2021) ... In 2013, the state program "Education Development 2013-2020" was approved, which provides for the federal project "Modern digital educational environment". The programs being implemented assumed the widespread introduction of ICT into the system of both school and higher education. The state begins to allocate budgetary funds to provide educational institutions with computer technology. This process took place slowly and gradually, but according to the Federal State Statistics Service, at the end of 2019, 97\% of educational organizations were equipped with personal computers and the same amount with the Internet (Osina et al., 2020; Rozhkova et al., 2020).

In 2017, the Government of the Russian Federation approved the program "Digital Economy of the Russian Federation", for the implementation of which it is required to provide the industry with qualified specialists (Mikheev et al., 2021; Tejedor et al., 2020). In 2019, a federal project "Human Resources for the Digital Economy" was prepared. This document determined the main directions for achieving the set goals by introducing new information technologies into the learning process (Krainov et al., 2021; Shcherbakova et al., 2021). Thanks to the approval of these projects, the concept of "digital literacy" has become widespread in Russia. A website "Digital Literacy" was developed, where anyone can test their knowledge or fill in the missing ones in various areas (Kaban \& Aşçı, 2021; Soldatova et al., 2013)

But, unfortunately, to date, the measures taken by state bodies remain insufficient to significantly increase the level of digital competence among the population. The ultra-rapid growth of the integration of digital and technology in society makes the need for digital literacy among students inevitable for success in both educational and professional fields. The rational use of digital devices, personal computers, gadgets, smartphones by society, especially the student community, is a step towards achieving global digital literacy. Digital platforms can be effective in the development of digital literacy when applied in a rational manner. But students who do not have digital literacy skills before using the Internet on their own may initially face difficulties before they can get to the site they need. Therefore, this problem must be solved systematically, in a multidisciplinary manner, with the involvement of qualified specialists. This can be achieved by including 
the study of digital literacy in the system of training young specialists in a higher education institution.

Both learners and educators need to have confidence in their digital skills to cope with the challenges of an evolving digital environment and economy. Educators must be digitally literate to help students participate in bridging the digital skills gap in today's digital age and create flexible learning environments. Digital proficient teachers and trainers should foster creativity by making learning more collaborative and improving students' problem-solving and communication skills (Purnama et al., 2021; Sánchez-Cruzado et al., 2021).

Technological integration into the education system has changed the meaning of the teacher for the learner from a passive person who transmits knowledge to an active teammate, mentor and curator on the way to achieving scientific heights and accustoming to self-education (Ronzhina et al., 2021; Sá \& Serpa, 2020). With the proliferation of all kinds of multimedia educational information content, teachers have gained access to new educational tools that serve as a catalyst to accelerate the development of digital literacy. But now the teacher himself needs to acquire the missing knowledge, skills of using ICT in pedagogy (Ghavifekr et al., 2016; llyina et al., 2019). Teachers need to reformat the learning process as soon as possible for the new rapidly changing conditions. Teachers need to keep up with the times, constantly update their knowledge, find and apply in practice new teaching methods, and improve them. The modern development of technology makes many demands on teachers, which are more and more difficult for teachers to meet every year. Therefore, it is necessary to find out the point of view of the teachers themselves in order to accelerate their integration into the new coordinate system of vocational education.

\section{RESULTS}

More than half of the teachers surveyed admit that they have insufficient knowledge in the field of digital technologies (Fig. 1). Teachers understand that in today's age of information technology, it is necessary to constantly improve and develop new competencies themselves.

Fig.1. Availability of digital competence among lectures

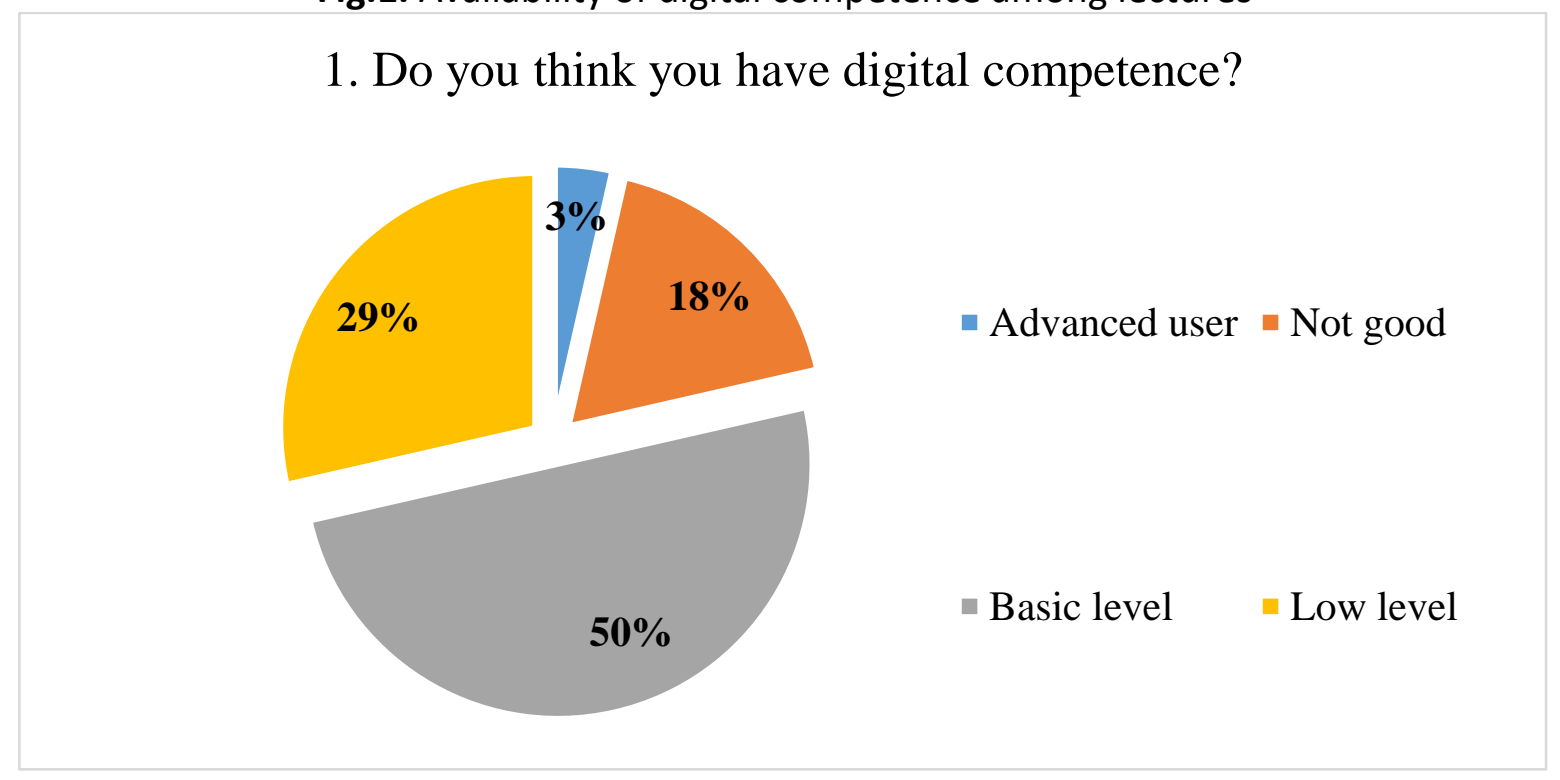

According to the respondents, one of the most important competencies that a teacher should have is digital. And also, almost $90 \%$ of teachers consider digital literacy to be an important competence for a teacher in a higher educational institution (Fig. 2). 
Fig.2. The importance of digital literacy for the educator

2. Is digital literacy an important part in the professor's work at the university?

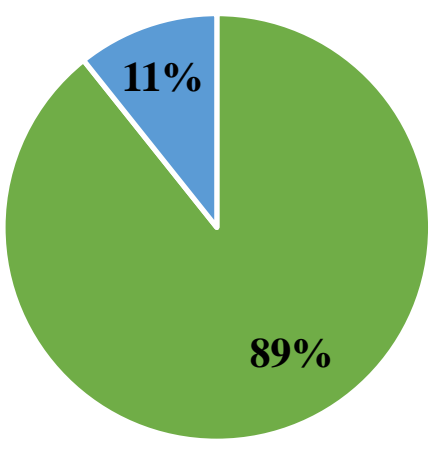

$\because$ Yes $\backsim$ No

In addition to self-improvement of the professors, teachers propose transforming the entire learning process to meet the changing requirements of the environment. But at the same time, teachers note that it is necessary to preserve part of the traditional education system (Fig. 3).

Fig.3. The need to modernize the learning process

3. Do you consider it is necessary to modernise the learning process in order to digitalize it?

No, traditional methods are more effective

5

Yes, but using traditional teaching methods

Yes, the educational process needs to be completely transformed

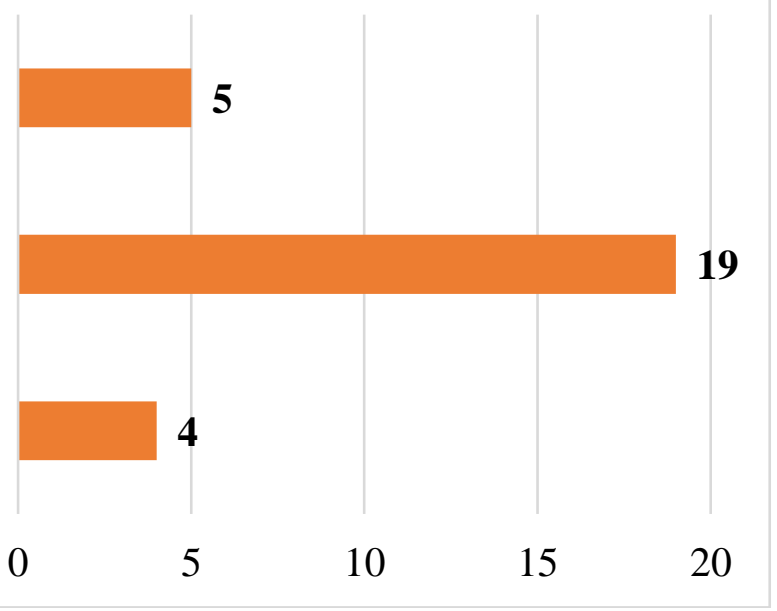

Most often, ICT tools are used by teachers outside the classroom when working with a group of students on research work. In the main course of study, teachers can use ICT as a means of broadcasting a lecture document on a projector screen (Fig. 4). 
Fig.4. Ways to integrate ICT into the curriculum

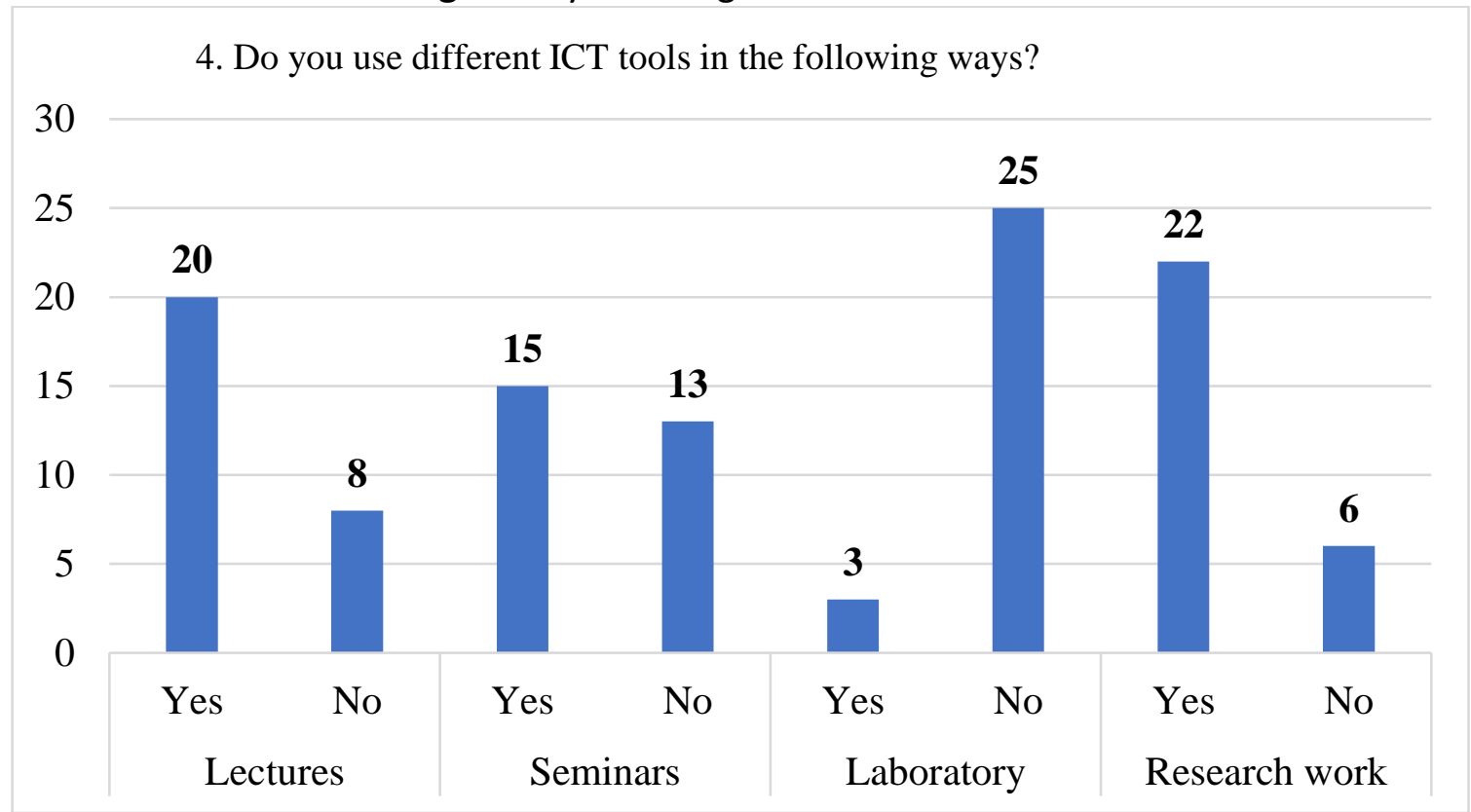

At the moment, modern educational platforms are practically not widespread among teachers. Teachers widely use only basic ICT programs, as well as the only educational support system Educon (Fig. 5).

Fig.5. Programs and learning platforms used by lecturers

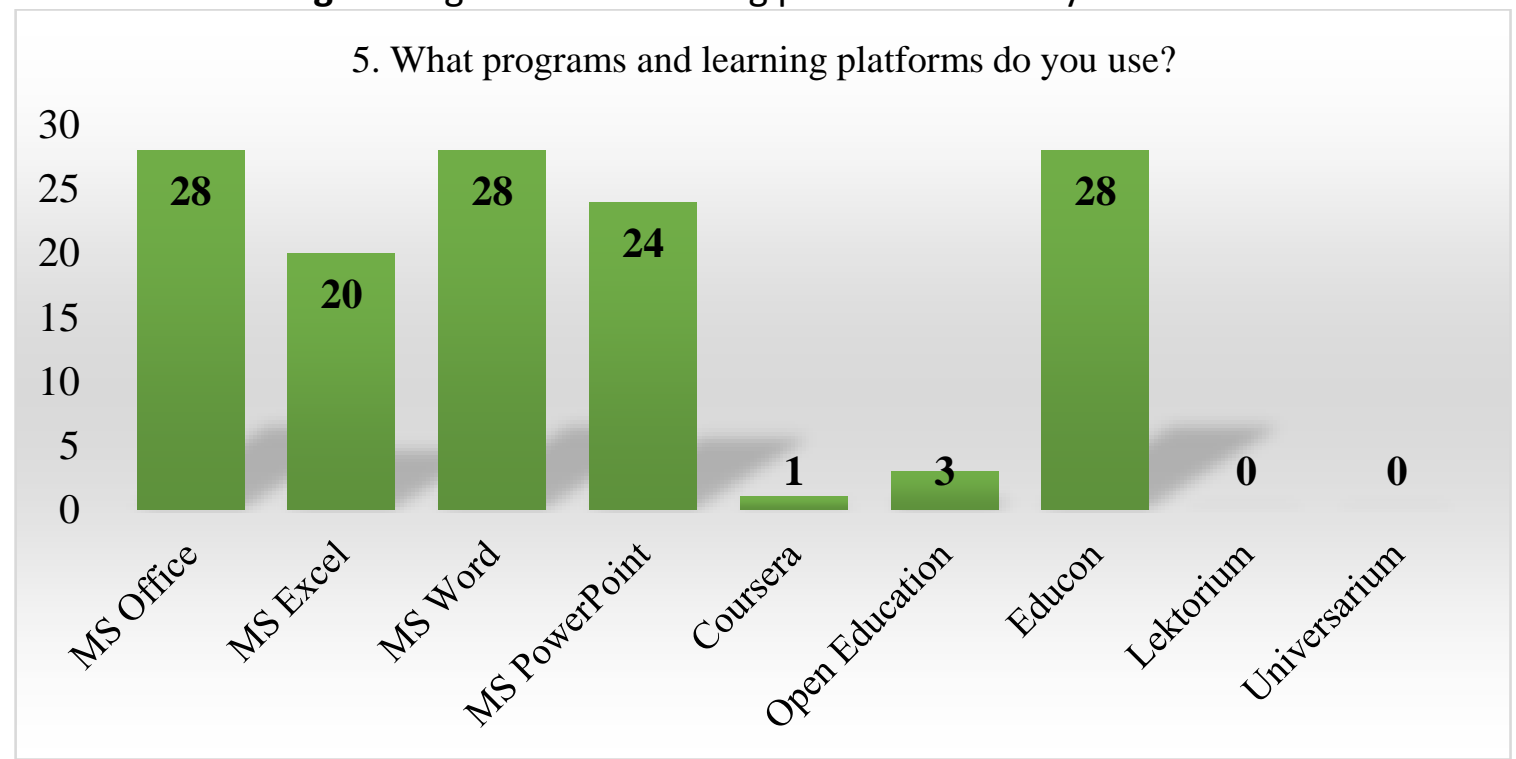

The most widespread Internet resource among the teaching staff is Social Networks (Fig. 6). Of all the possible ways of integrating the Internet into the learning process, it is Social Networks that are the most convenient and simple for teachers. 
Fig.6. Internet application used by lecturers

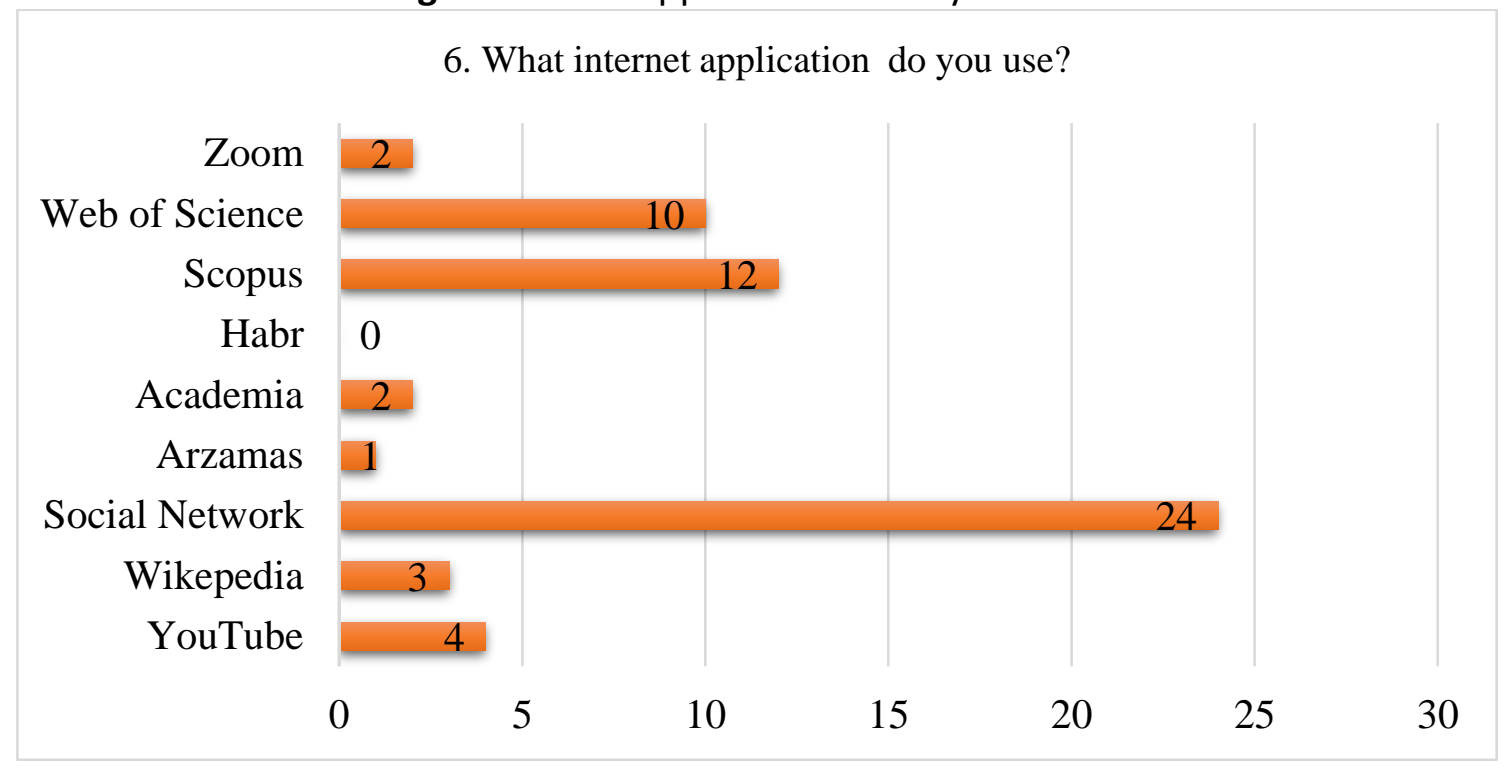

The main reason for such a low level of ICT implementation in the educational process is the lack of relevant skills and knowledge among the teaching staff. About half of all respondents are not at all confident in their strength, $36 \%$ sometimes experience slight difficulties and only $14 \%$ confidently use ICT in their needs (Fig. 7).

Fig.7. Confidence of lecturers in the ICT usage in the learning process

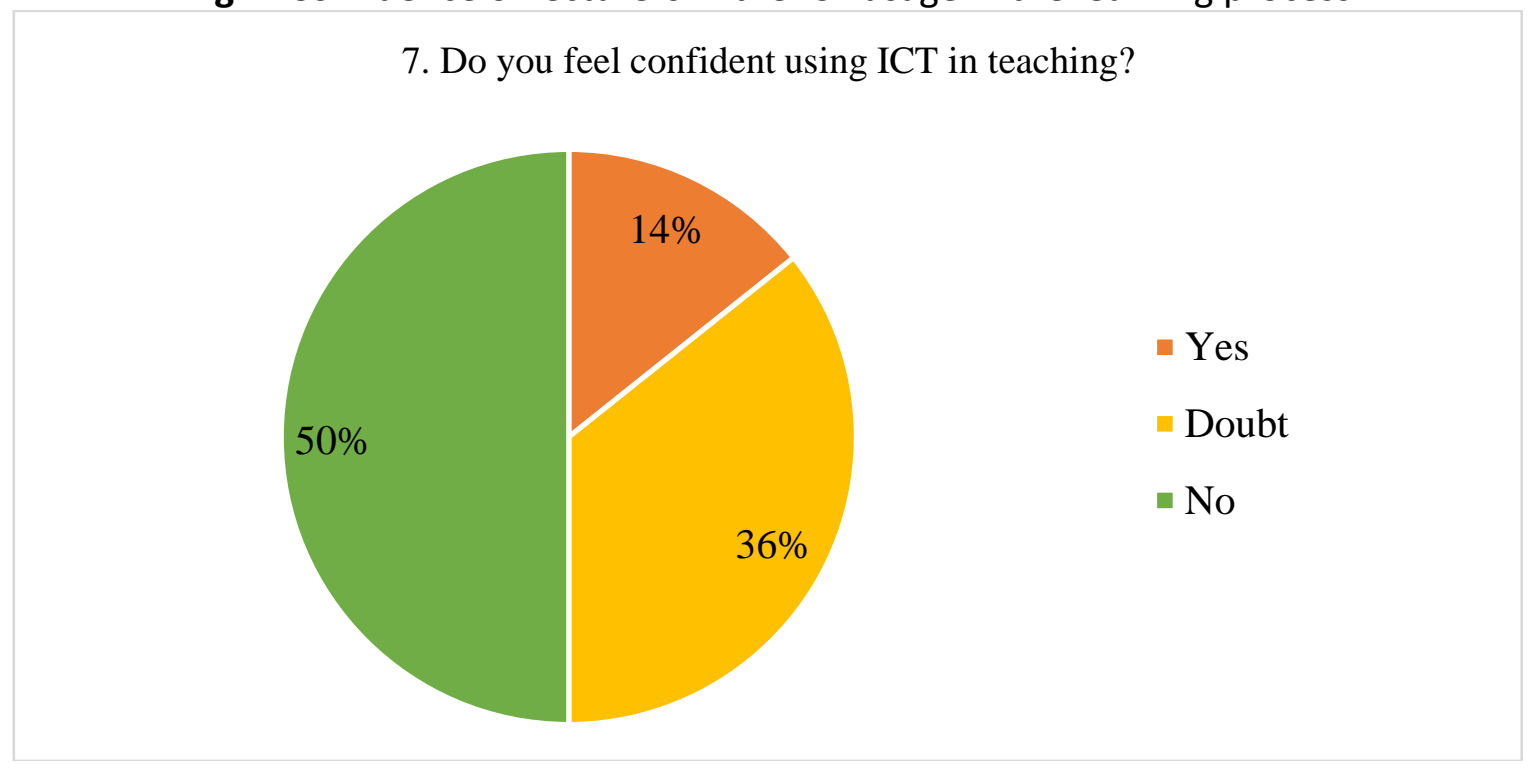

At the same time, almost all teachers did not undergo any systematic training in the skills of working with ICT tools (Fig. 8). 
Fig.8. Lecturers' ICT training

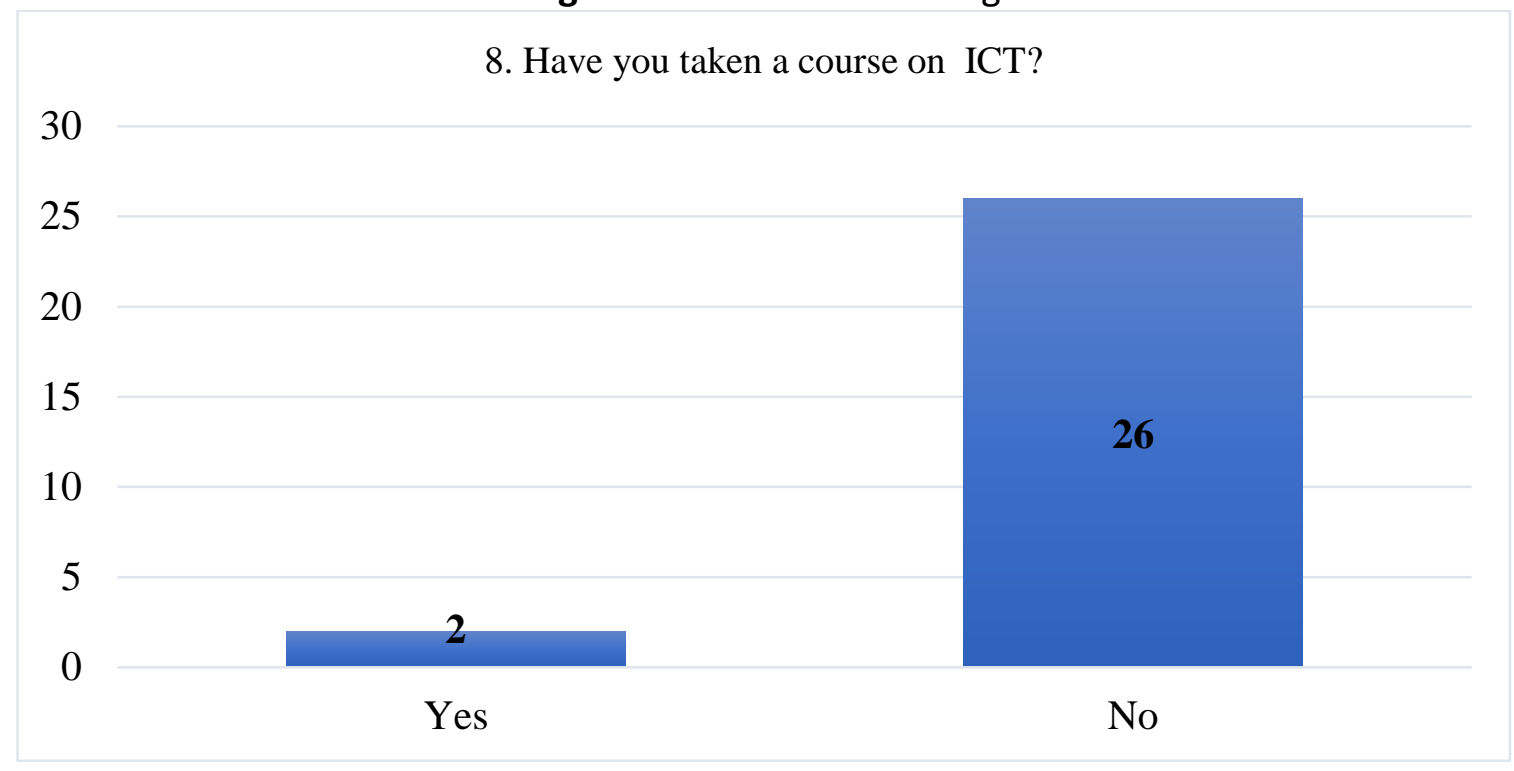

More than $95 \%$ of respondents are ready to take the necessary courses to obtain modern knowledge of the effective integration of ICT into the learning process (Fig. 9).

Fig.9. The need of lectures to get ICT tools knowledge

9. Would you like to improve your lnowledge and skills for effective application of ICT in your work?

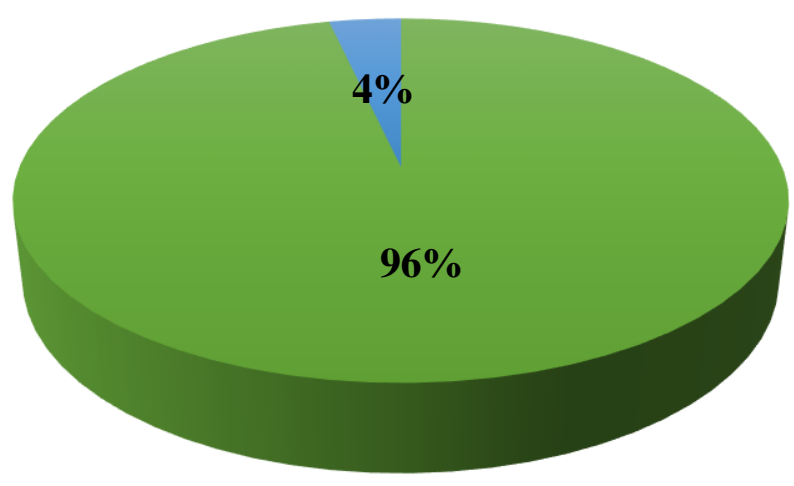

Yes $\square$ No

\section{CONCLUSION}

Based on the results of the study, it can be concluded that the level of knowledge of teachers about ICT tools, training platforms, and the possibilities of the Internet is not enough for the effective integration of modern digital technologies into the educational process. Despite the sufficient provision of higher educational institutions with computers and Internet connections, their potential is underutilized, which leads to a slowdown and decrease in the efficiency of the process of obtaining knowledge by students. The main reason for this problem is the insufficient competence of teachers in the use of ICT tools. Teachers themselves point out this state of affairs and are ready to be additionally educated. Therefore, the main recommendation for higher educational institutions will be the introduction of additional training for teaching staff in modern 
ways of conducting educational activities. It is possible to conduct seminars, lectures or courses for teachers, both short-term and long-term, on the basis of higher educational institutions.

On the part of the administrative building of the university, it is necessary to revise the curricula in order to introduce disciplines that imply the use of ICT. It is also possible to increase the requirements for newly admitted teachers, to check whether they have the appropriate competencies. In addition, it is necessary to motivate teachers to integrate ICT tools into the training system.

Authors' Contributions: Ibatova, A. Z.: conception and design, acquisition of data, analysis and interpretation of data, drafting the article, critical review of important intellectual content. Gromova, A. V.: conception and design, acquisition of data, analysis and interpretation of data, drafting the article, critical review of important intellectual content. All authors have read and approved the final version of the manuscript.

Ethics Approval: Not applicable.

Acknowledgments: Not applicable.

\section{REFERENCES}

Aydin, E., \& Erol, S. (2021). The views of Turkish language teachers on distance education and digital literacy during covid-19 pandemic. International Journal of Education and Literacy Studies, 9(1), 60-71. http://dx.doi.org/10.7575/aiac.ijels.v.9n.1p.60

Ghavifekr, S., Kunjappan, T., Ramasamy, L., \& Anthony, A. (2016). Teaching and Learning with ICT Tools: Issues and Challenges from Teachers' Perceptions. Malaysian Online Journal of Educational Technology, 4(2), 38-57.

https://eric.ed.gov/?id=EJ1096028.

Ilyina, E. A., Shchiptova, A. V., Poverinov, I. E., Grigoreva, S. V., Gorshkova, N. K., \& Fisunov, P. A. (2019). Features of the Development of the Digital Educational Environment in Russia. International Journal of Higher Education, 8(7), 121-131. https://doi.org/10.5430/ijhe.v8n7p121.

Kaban, A. L., \& Aşçı, S. (2021). COVID-19 Chronicles in Education: Overcoming Global Pandemic Challenges in Turkey by Empowering Educators to Become Digitally Literate. In New Student Literacies amid COVID-19: International Case Studies. Emerald Publishing Limited. https://doi.org/10.1108/S2055-364120210000041016.

Krainov, G. N., Panov, A. I., \& Zubkov, S. A. (2021). Challenges of digitalization for higher education in Russia. In SHS Web of Conferences (Vol. 103, p. 02011). EDP Sciences.

Kryukov, V. V., \& Shakhgeldyan, K. I. (2012). Information technology at the university: strategy, trends and experience. University Management: Practice and Analysis.

Livingstone, S. (2012). Critical reflections on the benefits of ICT in education. Oxford review of education, 38(1), 9-24. https://doi.org/10.1080/03054985.2011.577938.

Mikheev, A., Serkina, Y., \& Vasyaev, A. (2021). Current trends in the digital transformation of higher education institutions in Russia. Education and Information Technologies, 1-15. https://doi.org/10.1007/s10639-021-10467-6.

Miranda, G. L. (2007). The limits and possibilities of ICT in education. adventure in the search for knowledgewith Sisyphusfate of incessantly restarting the same task.". http://hdl.handle.net/10451/2824.

Osina, D. M., Tolstopyatenko, G. P., \& Malinovsky, A. A. (2020, May). Digitalization of higher legal education in russia in the age of covid-19. In International Scientific and Practical Conference (139, 392-398). Springer, Cham. DOI https://doi.org/10.1007/978-3-030-53277-2 47.

Pelgrum, W. J. (2001). Obstacles to the integration of ICT in education: results from a worldwide educational assessment. Computers \& education, 37(2), 163-178. https://doi.org/10.1016/S0360-1315(01)00045-8. 
Priyadarshini, A., \& Bhaumik, R. (2020). E-readiness of Senior School Learners to Online Learning Transition amid COVID-19 Lockdown. Asian Journal of Distance Education, 15(1), 244-256. Retrieved from https://www.asianjde.com/ojs/index.php/AsianJDE/article/view/456.

Purnama, S., Ulfah, M., Machali, I., Wibowo, A., \& Narmaditya, B. S. (2021). Does digital literacy influence students' online risk? Evidence from Covid-19. Heliyon, 7(6), e07406. https://doi.org/10.1016/i.heliyon.2021.e07406.

Ronzhina, N., Kondyurina, I., Voronina, A., Igishev, K., \& Loginova, N. (2021). Digitalization of Modern Education: Problems and Solutions. International Journal of Emerging Technologies in Learning, 16(4).

Rozhkova, D., Rozhkova, N., \& Blinova, U. (2020). Digital universities in Russia: digitization with extra speed. J. Digit. Sci., 2(1), 76-81. https://doi.org/10.33847/2686-8296.2.1 7.

Sá, M. J., \& Serpa, S. (2020). COVID-19 and the Promotion of Digital Competences in Education. Universal Journal of Educational Research, 8(10), 4520-4528.

Sánchez-Cruzado, C., Santiago Campión, R., \& Sánchez-Compaña, M. (2021). Teacher Digital Literacy: The Indisputable Challenge after COVID-19. Sustainability, 13(4), 1858. https://doi.org/10.3390/su13041858.

Shcherbakova, I. O., Belozerova, N. V., \& Mahmudova, T. V. (2021, February). Blended learning as a tool for professional training of specialists for the Arctic region: modern practices in the context of digitalization of education. In IOP Conference Series: Earth and Environmental Science (Vol. 678, No. 1, p. 012012). IOP Publishing. https://doi.org/10.1088/1755-1315/678/1/012012.

Soldatova, G., Zotova, E., Lebesheva, M., \& Shlyapnikov, V. (2013). Cifrovaya gramotnost'i bezopasnost'v internete: Metodicheskoe posobie dlya specialistov osnovnogo obshchego obrazovaniya [Digital literacy and Internet safety: A manual for specialists in basic general education]. Moscow: Google.

Tejedor, S., Cervi, L., Pérez-Escoda, A., \& Jumbo, F. T. (2020). Digital literacy and higher education during COVID-19 lockdown: Spain, Italy, and Ecuador. Publications, 8(4), 48. https://doi.org/10.3390/publications8040048.

Zemtsov, S., Barinova, V., \& Semenova, R. (2019). The risks of digitalization and the adaptation of regional labor markets in Russia. Фopcaŭm, $13(2$ (eng)).

Zulkarnain, Z., Heleni, S., \& Thahir, M. (2020, October). Digital literacy skills of math students through e-learning in COVID-19 era: a case study in Universitas Riau. In Journal of Physics: Conference Series (Vol. 1663, No. 1, p. 012015). IOP Publishing. https://doi.org/10.1088/1742-6596/1663/1/012015.

Received: 11 July 2021 | Accepted: 15 November 2021 | Published: 07 December 2021

This is an Open Access article distributed under the terms of the Creative Commons Attribution License, which permits unrestricted use, distribution, and reproduction in any medium, provided the original work is properly cited. 